\title{
RĪGAS POLITEHNISKĀ INSTITŪTA UN LATVIJAS UNIVERSITĀTES DARBINIECES ILONAS DUMPES (1891-1962) DZĪVES UN DARBA GAITAS
}

\section{ALĪDA ZIGMUNDE*,}

Rīgas Tehniskā universitāte

Kopsavilkums. Ilona Dumpe (1891-1962) ieguva mājskolotājas tiesības, taču izvēlējās kancelejas darbinieces darbu. Viña ir trešā sieviete Rīgas Politehniskā institūta (RPI) kancelejā un sāka tajā strādāt 1913. gadā. 1916. gadā vina sāka strādāt fabrikā «Provodṇik». 1919. gada februārī I. Dumpe atkal atgriezās augstskolā, uz RPI bāzes izveidotajā padomju Latvijas Augstskolā, pēc tam turpināja darbu dažādos amatos Latvijas Universitātē līdz 1944. gada augustam, kad devās emigrācijā. Par darbu saṇēmusi valsts apbalvojumus. Mūža nogali pavadījusi Vācijā, tulkojusi latviešu rakstnieku darbus vācu valodā.

Atslēgas vārdi: Ilona Dumpe, Rīgas Politehniskais institūts, LU kanceleja.

\section{Ievads}

Pēc 1917. gadā notikušajām politiskajām izmaiṇām Krievijā, kuras teritorijā toreiz vēl bija iekḷauta tagadējā Latvija un kur darbojās Pirmā pasaules kara laikā evakuētais RPI, augstskolās savu nozīmi zaudēja viduslaiku tradīcijas. Sievietes ieguva līdztiesību ar vīriešiem, un vinu vēlmei studēt nekādi šksēršl̦i netika likti. Citās valstīs, piemēram, Šveicē, sievietes studēja jau 19. gadsimta otrajā pusē, un turp devās vairākas sievietes arī no Kurzemes un Vidzemes. Algotu darbu precētas sievietes

* Korespondējošais autors.

E-pasts: alida.zigmunde@rtu.lv 
līdz 19. gadsimtam parasti nestrādāja, galvenās rūpes veltot gimenei un bērnu audzināšanai. Attīstoties pilsētām, tehnikai un nodibinot fabrikas, tajās arvien vairāk sāka strādāt arī sievietes. Pirmā sieviete RPI kancelejā sāka darbu 1898. gadā un turpmākajos gados līdzās vīriešiem sāka strādāt sievietes arī augstskolas bibliotēkā. 1913. gadā par kancelejisti RPI tika pieṇemta Ilona Dumpe, toreiz - Krieviṇa. Viṇa bija trešā sieviete, kura sāka strādāt augstskolas kancelejā, bet vairākums darbinieku toreiz vēl bija vīrieši.

Ilona Dumpe nāca no inteliǵentas ǵimenes un, līdzīgi kā citas meitenes 19. gadsimta beigās un 20. gadsimta sākumā, pārvaldīja vismaz divas svešvalodas, ieguva pamatizglītību un mājskolotājas tiesības. Viṇa meklēja algotu darbu un to atrada RPI kancelejā. Ir trīs sievietes, kuras dzimušas 19. gadsimta otrajā pusē un visu savu mūžu veltījušas gandrīz tikai RPI un vēlāk Latvijas Universitātei - Helēna Valdmane (1878-pēc 1944), Margrieta Akermane (1887-1972) un Ilona Dumpe (1891-1962). Par M. Akermanes dzīves darbību ir publicēts izsmel̦ošs raksts [1], H. Valdmanes dzìves pavediens ieskicēts saistībā ar viṇas vīra, RPI un LU sekretāra Aleksandra Valdmaṇa dzīves aprakstu [2], taču par I. Dumpes darbību līdz šim atrodamas visai skopas ziṇas. Pateicoties arhīvos un bibliotēkās pieejamiem dokumentiem un rakstiem, ir izdevies uzzināt kādreizējās RPI un LU darbinieces dzīves gājumu.

\section{Ilonas Dumpes gimene}

Kā liecina Ilonas Dumpes dzimšanas apliecība, vina ir dzimusi 1891. gada 29. maijā kā gleznotāja Reinholda Šterna (arī Zvaigznes) meita Ilona Konstance Šterna [3]. Viṇai bija četri krustvecāki - divas krustmātes un divi krusttēvi. Ilonas tēvs bija gleznotājs, tāpēc par krusttēviem vin,š izvēlējās gleznotājus Pēteri Bērtuli un Aleksandru Voitu. Nav zināms, kad un kāpēc Ilona tika adoptēta un kḷuva par Ilonu Krievinu. Viṇu adoptēja Juris, dokumentos saukts arī par Georgiju, Krieviṇš. Iespējams, ka adopcija sekoja pēc Ilonas vecāku nāves. Krieviṇu ǵimene centās dot Ilonai labu izglītību - viṇa mācījās RPI k̦īmijas profesora Heinriha Treija (1851-1917) sievas Johannas Treijas 2. šksiras sešklasīgajā privātskolā un beidza to 1905. gadā, bet 1910. gada maijā ieguva mājskolotājas tiesības vācu valodā un geogrāfijā [3]. Iespējams, ka viṇa ir strādājusi par skolotāju, taču I. Dumpes personāllietā šādu ziṇu nav.

Zināms, ka Krieviṇiem citu bērnu nebija un Ilonas audžumāte pēc Pirmā pasaules kara bija atraitne. Ilona uzturēja viṇu un rūpējās. Interesants ir fakts, ka pēc atgriešanās no evakuācijas Krievijā 1918. gada nogalē Ilona dzīvoja kopā ar Helēnu un Aleksandru Valdmañiem Tērbatas ielas 59/61. nama 5. dzīvoklī. Viṇi bija kolēǵi un, acīmredzot, kopā 
dzīvojot vairākus gadus, labi satika. Tikai 1927. gadā Ilona Krieviṇa pārgāja dzīvot uz namu G̣ertrūdes ielā 75 [4], kur dzīvoja viṇas nākamais vīrs. 1929. gada 22. jūnijā Ilona Rīgas evanǵēliski luteriskajā Pāvila baznīcā salaulājās ar vidzemnieku Bruno Dumpi (1896-1936) - Rīgas pilsētas Apgādības pārvaldes ierēdni.

Pēc apprecēšanās jaunā Dumpju gimene sāka dzīvot Kalnciema ielā 16. Kopā ar gímeni dzīvoja Elizabete Dumpe (1863-1944), domājams, Ilonas Dumpes vīratēva māsa [5]. Diemžēl pēc nepilniem septiniem laulībā pavadītiem gadiem I. Dumpe kḷuva atraitne, jo vinnas vīrs Bruno slimoja ar tuberkulozi, kas toreiz bija visai izplatīta slimība. Diemžēl Vainodes pagasta Saulkalnes sanatorijā vinam neizdevās slimību uzvarēt [6]. Pēc dzīvesbiedra nāves I. Dumpe turpināja rūpēties par vīra radinieci, taču dzīvesvietu ik pa laikam mainīja. Tā 1939. gada nogalē vina dzīvoja Upes prospektā Jūrmalā, Priedainē, pēc tam pārcēlās uz Vecrīgu, Audēju ielu, bet pēdējā viṇas dzīves vietas adrese Latvijā 1944. gadā bija toreizējā Vilhelma Purvīša, tagadējā Ausekḷa ielā 3 [7]. Starp citu, tur tolaik dzīvoja arī LU profesors Teodors Celms (1893-1989) ar ǵimeni.

1944. gada otrajā pusē I. Dumpe nolēma doties bēĝ̣u gaitās. Viñas aprūpējamās bija devušās aizsaulē un nekādi pienākumi pret tuviniekiem nebija par šķērsli vinasas izvēlei. I. Dumpe nonāca Vācijā, kur strādāja kopā ar tautiešiem. Viña 20. gadsimta 40. gadu beigās vai 50. gadu sākumā nesekoja citu piemēram un neemigrēja uz Ameriku. Zināms, ka Kanādā, Toronto, dzīvoja viṇas vīra brālis ar gimeni, ar kuru viṇa, domājams, uzturēja kontaktus [8]. Ilonas Krievinnas mūžs noslēdzās 1962. gada 7. aprīlī Bad Godesbergā Bonnas tuvumā, Vācijā.

\section{Darba gaitas Latvijā (1913-1944)}

Ilona Dumpe, toreiz Krieviṇa, Rīgas Politehniskajā institūtā sāka strādāt par kancelejas darbinieci gandrīz 22 gadu vecumā 1913. gada 16. maijā ar algu 25 rubḷi mēnesī. Augstskolā toreiz visa dokumentācija bija krievu valoda, bet kontaktos ar personālu nācās lietot arī vācu valodu. 1896. gadā par valsts mācību iestādi ar krievu mācību valodu reorganizētais RPI sāka darbu 1862. gadā kā privāta mācību iestāde ar vācu mācību valodu un tās nosaukums bija Rīgas Politehniskā skola (Rīgas Politehnikums). 20. gadsimta sākumā RPI strādāja dažādu tautību mācībspēki, tostarp vācbaltieši, kuri savā starpā un ar vācbaltiešu studentiem sarunājās vāciski. Taču I. Dumpei nebija problēmu komunicēt krievu un vācu valodā, jo skolā viṇa tās bija apguvusi pietiekami labi. Bez tam viṇa bija mācījusies arī franču valodu. 1915. gada vasarā sakarā ar Pirmā pasaules kara frontes tuvošanos RPI tika evakuēts uz Krieviju un oktobrī sāka darbu Maskavā. Evakuējās arī lielākā daḷa personāla, 
un I. Dumpe nonāca Maskavā, kur RPI kancelejā strādāja līdz 1916. gada 20. augustam. I. Dumpe lūdza viṇu atbrīvot no kancelejistes pienākumiem, jo bija atradusi citu darbu - gumijas fabrikā «Provodṇiks», kas arī bija evakuēta no Rīgas uz Maskavu. Fabrikā bijusī kancelejas darbiniece veica korespondentes-rēksinu vedējas pienākumus līdz 1918. gada septembrim [9]. Pēc tam sekoja atgriešanās Latvijā un darba meklējumi.

1918. gada augustā norisa daḷēja RPI evakuācija no Maskavas uz Rīgu. Lai gan liela daḷa inventāra, iekārtu un personāla palika Krievijā un uz RPI tehniskās bāzes, izmantojot mācībspēkus, augustā tika nodibināts Ivanovovoznesenskas Politehniskais institūts. 1. oktobrī RPI atsāka darbu vēsturiskajā ēkā Troṇmantnieka (tagad - Rainna) bulvārī 19 kā Baltijas Tehniskā augstskola. 1919. gada 3. janvārī augstskola darbu pārtrauca, bet 8. februārī tās vietā darbu sāka padomju varas uzturēta Latvijas Augstskola, kurā par kancelejas darbinieci - mašīnrakstītāju sāka strādāt Ilona Dumpe. Tas jaundibinātajā Latvijas Republikā bija nemierīgs laiks, jo mainījās valdības, iekārta un augstskolas nosaukumi. 22. maijā padomju varas dibinātā Latvijas Augstskola pārtrauca darbu, tad no 5. jūnija līdz 6. jūlijam darbojās Rīgas Tehniskā augstskola, bet 1919. gada 3. augustā Latvijas valdība izdeva rīkojumu par RPI slēgšanu un pārn,emšanu valdības rīcībā. Taču uz RPI materiālās bāzes tika veidota jauna nacionāla augstskola ar latviešu mācību valodu - Latvijas Universitāte, kuras nosaukums līdz 1923. gada augustam bija Latvijas Augstskola, un tai bija nepieciešami darbinieki.

No 1919. gada 1. septembra I. Dumpe tika pien,emta darbā Latvijas Augstskolas kancelejā par mašīnrakstītāju. Laikam ritot, amati main̄̄jās - no 1920. gada 1. janvāra viṇa bija žurnāliste, no 1. aprīḷa - arhivāre, bet no 1923. gada 1. aprīḷa - korespondente (arhivāre) - acīmredzot pildīja to pašu amatu, tikai tā nosaukums bija cits. Lai gan 1922. gadā augstskolas Budžeta komisija nolēma, ka pāris ierēdṇus jāatbrīvo no darba un pāris ierēdṇiem jāsamazina alga, Ilona palika strādāt ar mazāku algu. Kad tas bija iespējams, algu atkal palielināja. Pirmajos LR neatkarības gados cenas palielinājās, tāpēc, ievērojot lielo dzīves dārdzību, viṇai kā Latvijas Universitātes Galvenās kancelejas darbiniecei 1923. gada aprīlī algu paaugstināja - līdzšinējas algas - 400 rubḷu - vietā viṇa turpmāk saṇēma 475 rubḷus [10].

Līdz 1940. gada vasarai Ilona Dumpe strādāja LU dažādos amatos viṇa bija arhivāra palīdze LU Sekretariātā, dažreiz viṇu nosauca arī vienkārši par ierēdni, bet 1940. gadā pēc padomju varas nodibināšanās un augstskolas pārdēvēšanas par Latvijas Valsts universitāti viṇas amati bieži mainījās. No 1940. gada 1. oktobra I. Dumpe bija Rektorāta Vispārīgās dal̦as darbvede, no 10. novembra - Galvenās darbvedības daḷas kancelejas pārzine, bet no 1941. gada 20. marta - turpat tulkotāja no svešvalodām. 1941. gada vasarā, mainoties varām, tulkotāja I. Dumpe
Rīgas Politehniskā institūta

un Latvijas

Universitātes

darbinieces

Ilonas Dumpes

(1891-1962) dzīves un darba gaitas 
darbu turpināja Sekretariātā, bet rudenī vinas amats tika mainīts un turpmāk viṇa līdz 1943. gada decembrim strādāja par vecāko darbveditulkotāju, pēc tam līdz 1944. gada 2. augustam - par tulku [11].

I. Dumpes kolēǵi bija ne tikai LU Sekretariātā strādājošie Helēna un Aleksandrs Valdmaṇi, bet arī pēdējais LU, Otrā pasaules kara laikā - Universitātes Rīgā, sekretārs Jānis Vēliṇš (1907-1996), kurš bija studējis tieslietas un LU diplomu sanēma 1939. gadā. Brīvākos brīžos darbinieki atcerējās savu jaunību un studentus, kuri ir katras augstskolas pamats. Kancelejā jeb Sekretariātā studenti iegriezās bieži, dažreiz kādu studentu darbinieki atcerējās vēl gadiem ilgi, jo - vai nu lūgums bija īpašs vai pats students bija «īpašs». Satiekoties ar citiem kalpotājiem, nereti tika stāstīts par dažādiem atgadījumiem, kas izklausās pēc anekdotēm, tāpēc ḷoti labi paliek prātā. Minētajam J. Vēliṇam I. Dumpe esot daudz stāstījusi par Rìgas Politehniskā institūta studentiem, kuri Rīgā studēja pirms Pirmā pasaules kara. Viens no stāstiem bijis par kādu kaukāzieti, jo augstskolā studēja dažādu tautību jaunekḷi no dažādām toreizējās Krievijas impērijas vietām. Lai gan vairums studentu no Kaukāza bijuši apzinīgi un cìtīgi studējuši, neesot trūcis arī tā saucamo «mūžīgo studentu», kuri varēja

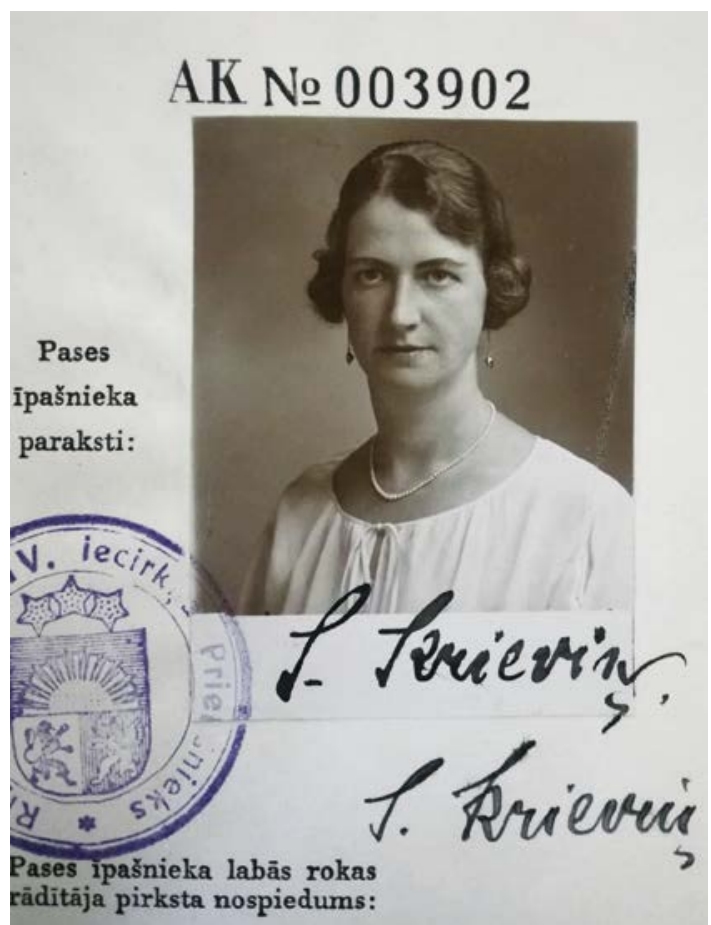

1. attēls. Ilona Dumpe (Krievina) 20. gadsimta 20. gadu sākumā [4]. 
atḷauties īrēt Rīgā dzīvokli, algot trīs kalpotājus un kalponi, saimnieci, kučieri un uzturēt pāris zirgus. Kāds students, kā stāstījusi I. Dumpe, «parasti piecēlies pēc jautri pavadītas nakts tā ap pusdienas laiku licis savam kučierim sevi vizināt vai nu pa Rīgas ielām, vai arī pa pilsētas tuvāko apkārtni, parasti pasakot kučierim kurp braukt. Kādu dienu studenta kungs nav bijis labā omā un uz kučiera vaicājumu, kurp lai kungu šodien ved, kučierim noteicis: «Aizved mani reiz uz tādu vietu, kur tu visretāk mani ved.» Kučierim tad arī nav bijis divreiz jāsaka: vin,š studenta kungu aizvedis uz - Politehnisko institūtu» [12].

LU darbinieki bija strādīgi un precīzi, tāpēc viṇus novērtēja Latvijas Republikas valdība. Apbalvojumus saṇēma pieminētie H. un A. Valdmaṇi, M. Akermane un, protams, I. Dumpe. 1934. gada 28. septembrī, atzīmējot LU 15 gadu jubileju, viṇa saṇēma Triju Zvaigžṇu ordeṇa I pakāpes goda zīmi [13]. Saistībā ar LU 20 gadu jubileju 1939. gada 28. septembrī LU aulā I. Dumpe saṇēma Atzinības krusta II pakāpes goda zīmi [14].

Domājams, ka I. Dumpe universitātē strādāja ar prieku un droši vien tur būtu strādājusi līdz pensijai, taču Otrā pasaules kara beigās daudzi viṇas tautieši un kolēgi devās trimdā. Viṇiem sekoja arī I. Dumpe, kuras darba gaitas Latvijā beidzās 1944. gada 2. augustā, kad viṇai piešķīra bezalgas atvalıinājumu uz nenoteiktu laiku [15].

\section{Dzīve emigrācijā (1944-1962)}

Doties emigrācijā I. Dumpe izvēlējās ne tāpēc, lai meklētu labākus dzīves apstāklụs. Līdzīgi kā citi, viṇa bija pieredzējusi, ka līdzcilvēkus un paziṇas, arī LU mācībspēkus un studentus, 1940. gadā atlaida no darba, apcietināja un nogalināja, bet 1941. gadā izsūtīja uz Sibīriju. Ilonas vīrs un arī kopjamā radiniece bija devušies mūžībā, bet vīra radinieki devās emigrācijā uz Rietumiem. Dzimtā Latvija viṇai noteikti bija dārga, te viṇa sagaidīja gan Latvijas Republikas proklamēšanu 1918. gada 18. novembrī, gan piedalījās LU, toreiz - Latvijas Augstskolas, atklāšanā 1919. gada 28. septembrī [16]. Ilona Krieviṇa nonāca Vācijā un tur pavadīja visus atlikušos gandrīz 18 dzīves gadus.

Vācijā I. Dumpe pelnīja sev iztiku Vācijā dibinātajā Baltijas Universitātē (1946-1949), kurā strādāja un studēja triju Baltijas valstu bijušie pilsoṇi, kuri bija devušies bēglu gaitās. Baltijas Universitātē bija nodibināta baltiešu literārā kopa, kas katru nedẹl̦u rīkoja visu triju tautu literārus vakarus vācu valodā. No latviešiem Ilona Dumpe piederēja pie kopas aktīvākajiem dalībniekiem [17]. Zināms, ka pārvietotās personas (arī dīpīši, bēgḷi) Blombergas nometnē Vācijā organizēja latviešu, lietuviešu un igauṇu dzejas un tautas dziesmu vakarus vācu valodā. Latviešu dzejas un tautas dziesmu tulkojumi vācu valodā bija I. Dumpes ziṇā [18], 
kura šo darbu veica labprāt. Zināmi ir vairāki kādreizējās kancelejistes, arhivāres un tulces tulkojumi. Pirmajos emigrācijā pavadītajos gados viṇa vācu valodā iztulkoja Mārtinna Zīverta lugu «Minhauzena precības», tā dodot iespēju autoram iekarot skatītāju simpātijas Vācijā. Latviešu izdevums «Nedēl̦as Apskats» 1946. gada beigās rakstīja, ka «tulkojums ir perfekts. Pārsteidz labi saglabāti Zīverta frazeologija un stils» [19]. Bez tam I. Dumpe tulkojusi arī citu rakstnieku un dzejnieku darbus, tostarp - bijušā RPI studenta Jāṇa Poruka dzeju [20].

Baltijas Universitāti 1949. gadā slēdza, taču Vācijā dzīvojošā Latvijas, Lietuvas un Igaunijas inteligence vēlējās pētīt savu tautu vēsturi, valodu, literatūru un citas kultūras nozares, darbā iesaistot attiecīgo tautu zinātniekus. Ar Rietumvācijas valdības materiālo atbalstu ar 1953. gada 1. janvāri Bonnā darbību sāka Baltijas pētīšanas institūts. Par tā Latvijas nodal̦as pirmo vadītāju kḷuva bijušais Baltijas Universitātes profesors, vēsturnieks un arheologs Eduards Šturms (1895-1959). I. Dumpe kḷuva par institūta sekretāri un šajā amatā strādāja vairākus gadus [21].

Latviešu ierēdnes I. Dumpes mūžs noslēdzās 70 gadu vecumā 1962. gada 7. aprīlī Baltiešu Kristīgo studentu mītnē Annabergā pie Bonnas [22].

\section{Nobeigums}

Bijusī RPI un LU darbiniece Ilona Dumpe apzinīgi veica savu darbu augstskolās un ir pelnījusi, ka vinuu godina un atceras. Atceroties pirmo sieviešu studiju sākumu RTU priekštecē RPI pirms 100 gadiem, 1917. gadā, jāgodina arī tās sievietes, kuras strādāja ar dokumentiem kancelejā, un, pateicoties vinu rūpēm, mūsdienās saglabājušās nozīmīgas liecības par senākās Latvijas augstskolas darbību.

Ilonas Dumpes un vinas kolēge RPI un LU Helēnas Valdmanes un Margrietas Akermanes biogrāfijās ir daudz līdzību - visas trīs bija precējušās, taču vinu dzimtām nebija turpinājuma. H. Valdmanes divi bērni nomira drīz pēc piedzimšanas, tāpēc gimenē vēlāk tika pieṇemts audžudēls. Par abu pārējo sieviešu vēlmi audzināšanā pien,emt kādu bērnu ziṇu nav. Visu triju minēto sieviešu darbs bija saistîts ar Rīgas Politehnisko institūtu un Latvijas Universitāti, augstskolās aizvadīts viṇu darba mūžs.

Salīdzinot darbu kancelejā 20. gadsimta pirmajā pusē un mūsdienās, jāsecina, ka tas toreiz tika augstu novērtēts - visas minētās sievietes, tostarp Ilona Dumpe, saṇēma valsts apbalvojumus. Lai gan viṇām nebija augstākās izglìtības, darbs tika padarìts labi, bet darbiniecēm bija labas vairāku valodu zināšanas, kas ḷāva talantīgi iztulkot pat pazīstamu rakstnieku darbus un iepazīstināt ar latviešu kultūru citas tautas. 


\section{AVOTU UN LITERATŪRAS SARAKSTS}

[1] Marihina, G. Latvijas Universitātes ierēdnes (1920-1957) Margrietas Akermanes (1887-1972) dzīvesdarbības raksturojums. No: LU raksti. Zinātṇu vēsture un muzejniecība, 814. sēj. Rīga: LU, 2016, 65.-73. lpp. [2] Zigmunde, A. Rīgas Politehniskā institūta un Latvijas Universitātes sekretārs Aleksandrs Valdmanis. Humanitārās un sociālās zinātnes. Zinātñu un augstskolu vēsture. 8. sēr., 7. sēj. Rīga: RTU, 2005, 103.-106. lpp.

[3] Latvijas Valsts vēstures arhīvs (turpmāk LVVA), 7427. f., 13. apr., 406. l., 35. a.-c. lp.

[4] LVVA, 2996. f., 4. apr., 15803. 1., 7.-12. lp.

[5] LVVA, 2942. f., 1. apr., 6176. 1., 53. lp.

[6] LVVA, 7427. f., 13. apr., 406. l., 14.lp.

[7] LVVA, 2942. f., 1. apr., 95. 1., 434.lp.

[8] Paziņojums par Ilonas Dumpes nāvi. Latvija Amerikā, 1962, Nr. 33, 4. lpp.

[9] LVVA, 7427. f., 13. apr., 406. 1., 3., 7. lp.

[10] Turpat, 7., 10., 15. lp.

[11] Turpat, 26., 28., 32., 34., 61., 62. lp.

[12] Vēlinšs, J. Universitāte bija viṇam visa dzīve. Austrālijas Latvietis, 1970, Nr. 1048, 5. lpp.

[13] Ar Triju zvaigžñu ordeñagoda zīmi apbalvoto 12. saraksts. Valdības Vēstnesis, 1934, Nr. 261, 6. lpp.

[14] Valsts prezidenta atzin̄̄ba universitātes darbiniekiem. Jaunākās Zingas, 1939, Nr. 220, 2. lpp.

[15] LVVA, 7427. f., 13. apr., 406. l., 34. lp.

[16] Vēliṇš, J. Atminnas un vērojumi par Latvijas Universitātes darbību neatkarības laikā. Universitas, 1972, Nr. 30, 9. lpp.

[17] Kultūras chronika. Latvija, 1949, Nr. 89, 5. lp.

[18] Nometnu dzive. Latvija, 1949, Nr. 120, 2. lpp.

[19] Pt. J. Mārtiṇam Zīvertam paveras cel̦š uz vācu skatuvēm. Nedēlas Apskats. Latvian weekly news, 1946, Nr. 14, 4. lpp.

[20] Slaucītājs, L. Dziesmas [notis]: solo balsij. III. Hempstead: autora izdevums, 1969, 24. lpp.

[21] Latvijas Nacionālās bibliotēkas A. Apīṇa Reto grāmatu un rokrakstu krājums, RX A 378, 76., 16. lp.

[22] Dažos vārdos. Laiks, 1962, Nr. 34, 8. lpp. 


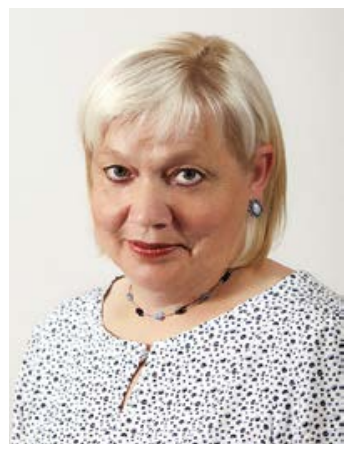

ALĪDA ZIGMUNDE, Dr. paed., was a specialist and Senior Researcher with the Museum of Riga Technical University from 1989-2007, and a Senior Researcher with Riga Technical University from 2007 to 2015. She is currently an Associate Professor with the Institute for Humanities and Head of the Department for Historic Research and Scientific Publications of the Research Centre for Engineering History of Riga Technical University. Her main academic interests include the history of pedagogy in Europe, history of education institutions and private schools, history of pedagogy at universities, history of engineering sciences and of universities.

Address: RTU Research Centre for Engineering History, Kronvalda bulvāris 1, Riga, LV-1010, Latvia

Phone: +37129869642

E-mail: alida.zigmunde@rtu.lv

Alīda Zigmunde

\section{The life and work of Ilona Dumpe (1891-1962) - an Employee}

\section{of Riga Polytechnic Institute and of the University of Latvia}

Ilona Dumpe (born Stern; after adoption - Krievina) was raised as a single child in a step-family. She got married, but her husband died quite early and she had to take care of his relatives. She received the education of a houseteacher, but decided to apply for a post at the Chancellery of Riga Polytechnic Institute (RPI) where she worked from 1913 to 1916. When RPI was founded, there were no female students, no female academic staff or female employees. In 1913, Ilona Dumpe was only the third woman employed at the Chancellery of RPI. Emancipation of women made its first steps. Until 1917, RPI had only male students and male teachers. When RPI was evacuated by the tsarist administration to Moscow, Ilona Dumpe moved to Moscow where she worked from 1916 to 1918 at the factory «Prowodnik» which had been evacuated to Moscow as well. When in 1919, RPI was dissolved and the Institution of Higher Education of Latvia was founded in the buildings of the defunct RPI she started to work there. In 1992, after the institution was renamed into the University of Latvia she took three different positions: in the archives, as a translator and as a typist. She received awards of the Government of Latvia for her skillful work. In 1944, at the end of World War II she immigrated to Germany like many Latvians. In Germany, she worked at the Baltic University from 1946 to 1949 and at the Baltic Research Institute in Bonn (Germany) founded in 1953. She has translated a number of works by Latvian writers. Ilona Dumpe died in 1962.

Keywords: Ilona Dumpe, Riga Polytechnic Institute, Chancellery of the University of Latvia. 
Алида Зигмунде

\section{Жизненный путь и трудовая деятельность сотрудницы Рижского политехнического института и Латвийского университета Илоны Думпе (1891-1962)}

Илона Думпе (она же Штерн, Криевиня; 1891-1962) выросла единственным ребенком в приемной семье. Позже вышла замуж, но муж вскоре умер. Приходилось заботиться об одиноких родственниках. И. Думпе получила права домашней учительницы, но выбрала работу в канцелярии. Стала третьей женщиной в канцелярии Рижского политехнического института, поступив туда на работу в 1913 году. С 1916 по 1918 год трудилась на эвакуированном в Москву заводе «Проводник». С 1919 года - вновь в системе высшего образования - в Латвийском университете (до 1922 года - Высшая школа Латвии), где исполняла обязанности архивариуса, секретаря и переводчицы. Ее работу отмечали в том числе правительственными наградами. В августе 1944 года вышла в отставку и отправилась в изгнание. Остаток жизни провела в Германии, где работала секретарем в Балтийском университете (1946-1949), потом в Балтийском исследовательском институте. Переводила на немецкий язык труды латышских писателей, таким образом пропагандируя латышскую культуру за границей. Скончалась в 1962 году недалеко от Бонна в возрасте семидесяти лет.

Ключевые слова: Илона Думпе, Рижский политехнический институт, канцелярия ЛУ.
Rīgas Politehniskā institūta

un Latvijas

Universitātes

darbinieces

Ilonas Dumpes

(1891-1962) dzīves

un darba gaitas 